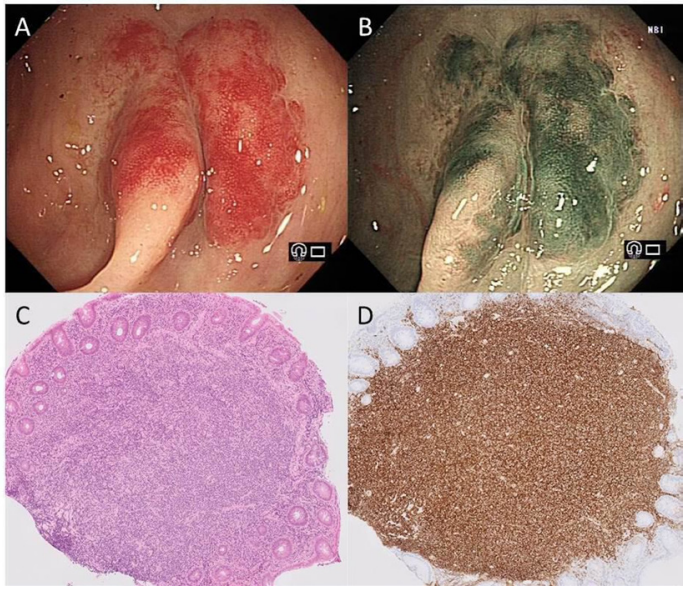

\title{
An unexpected cause of iron deficiency
}

\section{CLINICAL PRESENTATION}

A 70-year-old man presented with progressive weight loss and intermittent lower abdominal pain. Bowel habit was unchanged, there was no overt blood loss and there were no constitutional symptoms. His medical history included vascular Parkinson's, hypertension, osteoarthritis, type 2 diabetes mellitus and colonic polyps. His medications included pantoprazole and clopidogrel.

On physical examination, his abdominal and digital rectal examinations were unremarkable. Laboratory tests revealed normocytic (mean cell volume $84.1 \mathrm{fL})$ hypoferritinaemia $(15 \mu \mathrm{g} / \mathrm{L})$ with low haemoglobin $(123 \mathrm{~g} / \mathrm{L})$. Coeliac serology, other haematinics and immunoglobulin profile were normal. Urinalysis excluded haematuria.

Gastroscopy and duodenal biopsies were normal and urease test was negative for Helicobacter pylori. CT colonography identified a $22 \mathrm{~mm}$ proximal sigmoid lesion with a depressed centre concerning for extension beyond the bowel wall and in keeping with a T2/T3a non-metastatic cancer. The only other relevant findings were significant sigmoid diverticulosis and a $7 \mathrm{~mm}$ sessile polyp at the hepatic flexure. On subsequent endoscopy the proximal sigmoid lesion lay within a prominent diverticular segment; the overlying mucosa was very erythematous but smooth with a normal pit pattern (figure $1 \mathrm{~A}, \mathrm{~B}$ ). The central depression was more likely representative of a shallow diverticulum. On biopsy this felt relatively firm 
Editor's quiz: GI snapshot

\section{An unexpected cause of iron deficiency}

\author{
See page 1434 for question
}

\section{ANSWER}

Histopathological examination revealed morphological and immunophenotypic features of an extranodal marginal zone lymphoma of mucosa-associated lymphoid tissue (MALT lymphoma) (figure 1C,D).

First described in 1983 by Isaacson and Wright, ${ }^{1}$ MALT lymphoma can affect the GI tract, respiratory tract, breast, conjunctiva and salivary glands. Although the prevalence of GI MALT lymphoma is on the rise, involvement of the colorectum is rare in comparison with other sites $(<1 \%) .^{2-4}$ Typically colonic MALT lymphoma affects patients in the fifth to seventh decade of life, with approximately 50\% diagnosed on screening endoscopy. ${ }^{5}$ As in our case, there are reports of colonic MALT lymphoma presenting with weight loss and mild anaemia in the absence of B symptoms. ${ }^{2}$

The endoscopic appearance of colonic MALT lymphoma is variable, ranging from flat/epithelial and subepithelial lesions to polypoid and semipedunculated lesions. ${ }^{25}$ The surface characteristics can vary greatly; however, ulceration/erosions are rare in colonic compared with upper GI MALT lymphoma. ${ }^{2}$

Histologically it can be challenging to differentiate MALT lymphoma from florid reactive lymphoid tissue, especially in small biopsy specimens, owing to its lack of pathognomonic features. Clinicopathological correlation is therefore crucial. Colonic MALT lymphoma has an excellent prognosis and treatment depends on disease stage. Our patient was treated with rituximab monotherapy and responded well. The iron deficiency anaemia normalised within 6 months (haemoglobin $153 \mathrm{~g} / \mathrm{L}$, mean cell volume $94 \mathrm{fL}$, ferritin $80 \mu \mathrm{g} / \mathrm{L}$ ) and repeat colonoscopy confirmed complete resolution of the lesion.

Thomas Edward Conley $\odot,{ }^{1}$ Timothy Andrews, ${ }^{2}$ Arvind Arumainathan, ${ }^{3}$ Paul O'Toole, ${ }^{1}$ Philip J Smith, ${ }^{1}$ Sreedhar Subramanian ${ }^{1}$

${ }^{1}$ Gastroenterology, Royal Liverpool and Broadgreen Hospitals NHS Trust, Liverpool, UK

${ }^{2}$ Histopathology, Royal Liverpool and Broadgreen Hospitals NHS Trust, Liverpool, UK
${ }^{3}$ Haematology, Clatterbridge Cancer Centre NHS Foundation Trust, Wirral, UK

Correspondence to Dr Thomas Edward Conley, Gastroenterology, Royal Liverpool and Broadgreen Hospitals NHS Trust, Liverpool L7 8XP, UK; thomasconley@doctors.org.uk

Correction notice This article has been corrected since it published Online First. A typographical error in the title has been amended.

Contributors TEC and SS were involved in drafting and final revision of the manuscript. TEC, SS, TA, AA, PO and PJS were involved in editing and approval of the final version of the manuscript.

Funding The authors have not declared a specific grant for this research from any funding agency in the public, commercial or not-for-profit sectors.

Competing interests None declared.

Patient and public involvement Patients and/or the public were not involved in the design, or conduct, or reporting, or dissemination plans of this research.

Patient consent for publication Obtained.

Provenance and peer review Not commissioned; internally peer reviewed.

(C) Author(s) (or their employer(s)) 2021. No commercial re-use. See rights and permissions. Published by BMJ.

\section{Check for updates}

To cite Conley TE, Andrews T, Arumainathan A, et al. Gut 2021;70:1579.

Received 14 May 2020

Accepted 21 May 2020

Published Online First 16 June 2020

Gut 2021;70:1579. doi:10.1136/gutjnl-2020-321830

ORCID iD

Thomas Edward Conley http://orcid.org/0000-0002-0604-0770

\section{REFERENCES}

1 Isaacson P, Wright DH. Malignant lymphoma of mucosa-associated lymphoid tissue. A distinctive type of B-cell lymphoma. Cancer 1983;52:1410-6.

2 Hollie N, Asakrah S. MALT lymphoma of the colon: a clinicopathological review. J Clin Pathol 2020:jclinpath-2019-206377.

3 Gay ND, Chen A, Okada CY. Colorectal lymphoma: a review. Clin Colon Rectal Surg 2018:31:309-16.

4 Howell JM, Auer-Grzesiak I, Zhang J, et al. Increasing incidence rates, distribution and histological characteristics of primary gastrointestinal non-Hodgkin lymphoma in a North American population. Can J Gastroenterol 2012;26:452-6.

5 Jeon MK, So H, Huh J, et al. Endoscopic features and clinical outcomes of colorectal mucosaassociated lymphoid tissue lymphoma. Gastrointest Endosc 2018;87:529-39. 